\title{
THE HELMINTH PARASITOFAUNA OF BUFO REGULARIS (REUSS) IN AWKA, ANAMBRA STATE, NIGERIA
}

\author{
NWORAH D.C. *, OLORUNFEMI O.J. \\ Department of Human Physiology,Faculty of Basic Medical Sciences, College of Health Sciences, University of Port Harcourt, \\ Choba, Rivers State, P.M.B. 5323, Nigeria \\ *Corresponding author. E-mail: doris4white@yahoo.com, drdoriswhite@gmail.com
}

Received: June 15, 2011; Accepted: September 07, 2011

\begin{abstract}
The term "toad" tends to refer to the "True Toads"... which are members of the family Bufonidae, containing more than 300 species. One hundred specimens of Bufo regularis (67 males and 33 females) were collected between June 2006 and August 2006 in Awka metropolis of Anambra State of Nigeria and examined for helminth parasites or for non-protozoan gut and tissue parasites. Seventy one percent (71\%) (48 males and 23 females) of the specimens were infected by five hundred and forty-three (543) parasitic helminthes made up of $475(89 \%)$ nematodes, $6(2 \%)$ pentastomids and $62(14 \%)$ trematodes. These seven species collected include Nematoda: Ascaridoid larva (12\%), Rhabdias bufonis(30\%), Camallanus sp.(10\%), Amplicaecum africanum(31\%), Ascaridoid(6\%); Trematoda: Messocoelium monodi(14\%); Pentastomida: Raillietiella sp.(6\%).

Amplicaecum africanum was most prevalent in males with $24 \%$ than in females $7 \%$. Also Rhabdias bufonis was most prevalent in males with $19 \%$ than in females $11 \%$ and the differences were statistically significant. Prevalence also varied with length and weight. Male toads in the length classes of $11.0-11.9 \mathrm{~cm}$ and $12.0-12.9 \mathrm{~cm}$ had the highest prevalence of $100 \%$ while those in 7.0 $7.9 \mathrm{~cm}$ length class had the least prevalence of $60 \%$. Females in the $10.0-10.9 \mathrm{~cm}$ length class had the highest prevalence of $81.82 \%$ while those in $9.0-9.9 \mathrm{~cm}$ length class had the least prevalence of $50 \%(P<0.05)$. Males in $101-120 \mathrm{~g}$ weight class had the highest prevalence of $100 \%$ while those in the $61-80 \mathrm{~g}$ weight class had the least prevalence of $63.64 \%$. Females in $141-160 \mathrm{~g}$ weight class had the highest prevalence of $100 \%$ while those in the weight classes of $41-60 \mathrm{~g}, 61-80 \mathrm{~g}$ and $81-100 \mathrm{~g}$ had the least prevalence of $75 \%$ and the differences were statistically significant. $(P<0.05)$. All the helminths exhibited site preferences except one nematode, Amplicaecum africanum, recovered from rectum, intestine and stomach of both male and female toads. Parasite abundance was variable from one toad size class to another. It appeared that there was a general tendency for the prevalences to increase with increase in size of the host.
\end{abstract}

Keywords- Bufo regularis, helminth parasites, prevalence, intensity, nematode, trematoda, pentastomida and host.

\section{Introduction}

Toads are fat-bodied, have warts, can live in drier climates, where most frogs usually live in or near water. In particular, this toad has been recorded from the following countries: Senegal, Gambia, Guinea Bissau, Sierra Leone, Liberia, Guinea, Mali, Burkina Faso, Ivory Coast, Ghana, Benin, Niger, Nigeria, Cameroon, Equatorial Guinea, Gabon, Angola, Congo, R.D. Congo, Chad, Central African Republic, Algeria, Libya, Egypt, Sudan, Ethiopia, Eritrea, Uganda, Rwanda, Kenya. But they are most abundant in the tropical regions. This species is widespread in savanna regions south of the Sahara [1].

According to [13], typical $B$. regularis are found in a region stretching from Senegal through West Africa to Central Africa and through North Africa to Egypt. Amphibian parasitism has been used as a model for understanding very important issues pertaining to the evolution of parasites and their hosts, life cycles, host-parasite relationships, etc. Toads are less common inhabitants of water than frogs and thus are less exposed to infection by larval trematodes. Helminth parasites may result from factors such as dirty environment and poor quality of food taken. The study of parasites of $B$. regularis and other anurans have been undertaken by few parasitologists. The number of parasites necessary to cause harm to $B$. regularis varies considerably with the size of the host and health status [4].

The helminth parasites of anurans from the five locations in the savannah-mosaic and one in the transitional vegetation zone of Edo State of Nigeria were investigated [5] and reported a work done with a total of 200 adult male toads (B. regularis) captured from Assiul locality (Upper Egypt), the toads were examined for the testicular infection with Myxobulus sp. They discovered that ten toads showed various degree of infectivity detected by means of light and electron microscopy; [11] reported that arthropods and predominantly ants and termites as prey; [12] mainly found ants in dissected specimens [14] reports on a diet comprising ants, beetles, termites, spiders, orthopterans, butterflies and flies, with variations of the diet spectrum depending on the respective seasons and altitudes. If the weather happens to be rather wet, the proportion of termites increases considerably. According to [10], this species has specialized on ants. 


\section{CLASSIFICATION}

Toads are classified in the phylum -Chordata, subphylum Vertebrata, class -Amphibia, order -Anura. The genus that includes more than 300 species is Bufo of the family Bufonidae. Besides Bufo, the family includes 25 genera.

\section{MATERIALS AND METHODS}

Host sex was determined by observation of reproductive organs. All parasitic helminths were preserved, stained (when necessary), and mounted using standard techniques.

\section{Identifications of helminth taxa}

This was carried out using descriptions from the literature [2-9].

Terminology used in the explanation and for identification of parameters

Use of ecological terms follows [10]. Parameters include prevalence, intensity, mean intensity, mean abundance From July 2006 to August 2006, 100 specimens of Bufo regularis (33 females and 67 males ) were collected at night by hand picking with gloves on from three (3) different locations in Awka metropolis namely: Temporary site Nnamdi Azikiwe University, St John of God Road and Mano road at different time intervals.

\section{The measurement}

The freshly killed toads were weighed using an electronic weighing balance. The snout-vent length of the toads were measured using a thread and meter rule.

\section{Determination of sex of Bufo regularis}

The sexes were determined by two methods. The first was through the color of the throat. The second was through the reproductive system [13]. The throat of the male is dark or green whereas that of the female is white. Females have coiled oviducts which are absent in males.

\section{Killing of the Bufo regularis and preservation}

The toads were sacrificed in a sealed jar using chloroform. They were dissected by pinning them with office pins to hold them in a waxed bowl and pouring water to cover the body of the specimen. The bodies of the $B$. regularis after dissection were preserved in $4 \%$ formaldehyde solution.

\section{Examination of $B$. regularis for parasites}

The body cavity, digestive tract,intestine, heart, lungs, gall bladder, stomach, rectum, liver and kidneys were examined for parasites. Each organ was excised and placed in a separate petri-dish which contained normal saline $(0.9 \% \mathrm{w} / \mathrm{v})$ and thoroughly searched for helminth parasites, using magnifying lens and a dissecting microscope.

\section{Collection of parasites and preservation}

Helminth parasites were picked with dissecting needle (forcep) and washed in normal saline. Trematodes and nematodes were immediately fixed in AFA ( Alcoholformalin-Acetic Acid) solution / were kept in $70 \%$ ethyl alcohol, while the Penntastomides were killed with hot $70 \%$ alcohol heated approximately to $60^{\circ} \mathrm{C}$ and were preserved in total $70 \%$ alcohol or in AFA.

All recovered parasites were confirmed by specialists/ parasitologists.

\section{Food materials collected}

A variety of insects and other invertebrates including snails, beetles, earthworms were collected from the oesophagus and preserved in $4 \%$ formaldehyde solution.

\section{DISCUSSION}

In the infested B.regularis examined, the occurrence and prevalence of parasites recovered were four hundred and seventy-five (475) nematodes (89\%), 62 trematodes (14\%), and 6 pentastomids( $2 \%$ ). The study showed a higher prevalence of nematodes followed by trematode and pentastomid in both male and female toads. The higher prevalence of parasites in male toads $(71.64 \%)$ than in female toads $(69.70 \%)$ is in line with [1] who reported that out of 59 toads examined, 52 were infested (33 of 36 males and 19 of 23 females). The result of this research as reported in table 1 , showed that six parasites made up of five nematodes, one trematode and a pentastomid infested the $B$. regularis population at Awka. This finding is in many respect similar to the result of [12] who recovered five nematodes, one cestode and one trematode in their study of helminth paasitofauna of the same amphibians in lle-lfe, Nigeria. It would seem that nematodes are the known prevalent parasites of B.regularis in Nigeria.

From table 1 of this study, Amplicaecum africanum with $31 \%$ prevalence was the most prevalent species infesting B.regularis in Awka. It also had the highest prevalence of $24 \%$ in table 3 with mean intensity of 5.04 . This is in accordance with the observation of [11], [12] to the effect that it is the main species found in rain forest and mangrove forest of South Western Nigeria.

From the findings in the present study (table 1) Rhabdias bufonis which is a species of nematode had the highest prevalence of $11 \%$ and a mean intensity of infection 6.18 . the species was found only the lungs of the toads. This finding is in keeping with the report of [13] who noted that $R$. bufonis are lung parasites of amphibians.

The result of this study as reported in table 4, showed that Raillietiella sp.,was recoverd from the lungs of female B. regularis . this is line with the findings of [11], on the endoparasites of amphibians from South western Nigeria who recovered Raillietiella sp.,from the lungs of some $B$. regularis . It would therefore seem that Raillietiella $\mathrm{sp}$, is a widely occurring parasite of B.regularis in southern Nigeria. The result of this research as reported in tables 3 and 4 , showed that A.africanum infested the stomach and intestine of both male and female toads. This is in line with [12] who recovered the same nematode from both stomach and intestine of $B$. regularis intestine in their study of helmith parasite fauna of B.regularis Amphibian in lleIfe,Nigeria; [14] reported on helminth parasites of anurans from the savannah mosaic zone of southern Nigeria. Polystoma prudhoei which was originally described from P.oxyrhynchus in B. regularis was a new host record for the parasite discovered. They were of the view that the larval 
ascaridoid found in a number of the anuran host and the larvae of Abbreviata sp found in D. occipitalis are most probably parasites of snakes and other reptiles that use amphibians as transport hosts. Most of the parasite found in the study were being reported for the first time in Nigeria, but a number of them have a distribution in other African countries.

According to [10], the prey of $B$. regularis often includes ants, beetles, bugs, insects, grubs, slugs, worms, and other invertebrates like other amphibians do. As tadpoles, they eat plants. Toads, as pets, will eat fruit or vegetables. But toads in the garden, as insect eaters, should be valued for their role in pest-control!

\section{CONCLUSION AND RECOMMENDATION}

This study has revealed that males of B.regularis are highly infested. Amplicaecum africanum is the most prevalent species of nematode infesting Bufo regularis in Awka. The absence of cestoda needs to investigated. Nematodes were the most prevalent followed by trematode and penastomid. Generally, the parasitofauna of Bufo regularis in Awka is similar to those of the parasite populations from the rain forest areas of Nigeria. This work comes in time to open the door for further research on amphibian parasitism. Amphibian parasitism has used as a model for understanding very important issues pertaining to the evolution of parasites and their hosts, life cycles, hostparasite relationships, etc. Toads are less common inhabitants of water than frogs and thus were lesser exposed to infection by larval trematodes.

\section{References}

[1] Rödel M.O. (2000) Amphibians of the West African Savanna. Edition Chimaira, Frankfurt, Germany.

[2] Hedrick L.R. (1935) Trans. Am. Micr. Soc., 54(4),307-335.

[3] Ward H. L. (1940) Trans. Am. Micr. Soc., 59(3),327-347.

[4] Schacher J. F. and Crans W.J. (1973) J. Parasitol., 59(4),685-691.

[5] Brooks D.R. (1976) Bull. Univ. Nebr. St. Mus., 10(2),65-92.

[6] Kennedy M. J. (1981) Can. J. Zool., 59(9), 1836-1846.

[7] Prudhoe S. and Bray R.A. (1982) Platyhelminth parasites of the Amphibia. Oxford University Press. Oxford, U.K., 217pp.

[8] Baker M. R. (1986) Can. J. Zool., 64(1),228-237.

[9] Esslinger J. H. (1986) Proc. Helminthol. Soc. Wash., 53(2):218-223.

[10] Bush A. O., Lafferty K. D., Lotz J. M. \& Shostak A. W. (1997) J. Parasitol., 83(4),575-583.

[11] Siaka Aisien O, Ugbo Anthonia D., llavbare Aretha N., Ogunbor Omoyemwen (2001) Acta Parasitologica, Vol.46( 4) , 299-305

[12] Ayodele H.A. and Akinpelu A.I. (2004) Ife Journal of Science Vol.6(2) 2004, 101-104

[13] Goldberg S. R., Bursey C.R. and.Cheam H. (1998) J. Parasitol., 84(1),175-177.
[14] Siaka A.O., Ajakaiye E.B. and Braimoh K. (2003) Acta Parasitologica 48(1), 47-54. 
Table 1-Prevalence of the different parasite species in the study population of Bufo regularis.

\begin{tabular}{|l|l|l|l|l|l|l|l|l|}
\hline $\begin{array}{l}\text { Parasites } \\
\text { Species }\end{array}$ & $\begin{array}{l}\text { Total } \\
\text { num of } \\
\text { both } \\
\text { sexes }\end{array}$ & $\begin{array}{l}\text { No } \\
\text { infected } \\
\text { in males }\end{array}$ & $\begin{array}{l}\text { No } \\
\text { infected } \\
\text { in } \\
\text { females }\end{array}$ & $\begin{array}{l}\text { Total } \\
\text { no } \\
\text { infected }\end{array}$ & $\begin{array}{l}\text { Prevalence( } \\
\%)\end{array}$ & $\begin{array}{l}\text { Total } \\
\text { parsites } \\
\text { collecte } \\
\text { d }\end{array}$ & $\begin{array}{l}\text { No of } \\
\text { parasites per } \\
\text { infected } \\
\text { host(range) }\end{array}$ & $\begin{array}{l}\text { Mean } \\
\text { intensity }\end{array}$ \\
\hline $\begin{array}{l}\text { Nematodes: } \\
\text { Ascaridoid } \\
\text { larva }\end{array}$ & 100 & 6 & 6 & 12 & 12 & 58 & $1-15$ & 4.83 \\
\hline Ascaridoid & 100 & 5 & 1 & 6 & 6 & 14 & $1-6$ & 2.33 \\
\hline R. bufonis & 100 & 19 & 11 & 30 & 30 & 208 & $1-95$ & 6.93 \\
\hline Camallanus sp & 100 & 8 & 2 & 10 & 10 & 37 & $1-12$ & 3.70 \\
\hline A. africanum & 100 & 24 & 7 & 31 & 31 & 158 & $1-18$ & 5.10 \\
\hline $\begin{array}{l}\text { Trematode: } \\
\text { M. monodi }\end{array}$ & 100 & 9 & 5 & 14 & 14 & 62 & $1-11$ & 4.43 \\
\hline $\begin{array}{l}\text { Pentastomid: } \\
\text { Raillietiella sp }\end{array}$ & 100 & - & 2 & 2 & 2 & 6 & $2-4$ & 3.00 \\
\hline
\end{tabular}

[10] Statistically $X^{2} \mathrm{Cal}=51.08, \mathrm{df}=6, \mathrm{p}<0.05$ )

Rhabdias bufonis, Amplicaecum africanum, Mesocoelium monodi

Table 2 -Prevalence of parasite infection in relation to sex:

\begin{tabular}{|l|l|l|l|}
\hline Sex & No. examined & No infected & Prevalence $(\%)$ \\
\hline Male & 67 & 48 & 71.64 \\
\hline Females & 33 & 23 & 69.70 \\
\hline Total & 100 & 71 & \\
\hline
\end{tabular}

[10] Statistically $\left.X^{2} \mathrm{Cal}=11.56, \mathrm{df}=1, \mathrm{p}<0.05\right)$

Table 3-Distribution of the different parasites within male Bufo regularis

\begin{tabular}{|c|c|c|c|c|c|c|c|}
\hline Location & Parasite species & No found & $\begin{array}{l}\text { No } \\
\text { infected }\end{array}$ & Prevalence & $\begin{array}{l}\text { Total no of } \\
\text { parasites } \\
\text { collected }\end{array}$ & $\begin{array}{l}\text { Mean } \\
\text { intensity }\end{array}$ & $\begin{array}{l}\text { Mean } \\
\text { abundance }\end{array}$ \\
\hline Oesophagus & $\begin{array}{l}\text { a. A. larva } \\
\text { b. Camallanus sp } \\
\text { c. Ascaridoid } \\
\text { d. M. monodi }\end{array}$ & $\begin{array}{l}3 \\
5 \\
6 \\
1\end{array}$ & 8 & $\begin{array}{l}4.48 \\
7.46 \\
8.96 \\
1.49\end{array}$ & 15 & 1.88 & 0.22 \\
\hline Stomach & $\begin{array}{l}\text { a.A. africanum } \\
\text { b.Camallanus sp } \\
\text { c.M. monodi }\end{array}$ & $\begin{array}{l}81 \\
2 \\
9\end{array}$ & 17 & $\begin{array}{l}120.90 \\
2.99 \\
13.43\end{array}$ & 92 & 5.41 & 1.37 \\
\hline Intestine & $\begin{array}{l}\text { a. A. larva } \\
\text { b. M monodi } \\
\text { c. Camallanus sp } \\
\text { d.A.africanum } \\
\text { e.Ascaridoid }\end{array}$ & $\begin{array}{l}24 \\
36 \\
23 \\
24 \\
6\end{array}$ & 21 & $\begin{array}{l}35.82 \\
53.73 \\
34.33 \\
35.82 \\
8.46\end{array}$ & 113 & 5.38 & 1.69 \\
\hline Rectum & $\begin{array}{l}\text { a.A. africanum } \\
\text { b.R. bufonis }\end{array}$ & $\begin{array}{l}11 \\
5\end{array}$ & 3 & $\begin{array}{l}16.42 \\
7.46\end{array}$ & 16 & 5.33 & 0.24 \\
\hline Lungs & $\begin{array}{l}\text { a. R. bufonis } \\
\text { b.Camallanus sp } \\
\text { c.M. monodi }\end{array}$ & $\begin{array}{l}135 \\
1 \\
1\end{array}$ & 18 & $\begin{array}{l}201.49 \\
1.49 \\
1.49\end{array}$ & 137 & 7.61 & 2.04 \\
\hline $\begin{array}{l}\text { Visceral } \\
\text { cavity }\end{array}$ & a.A. africanum & 2 & 1 & $\begin{array}{l}1.49 \\
3.03\end{array}$ & 2 & 2.00 & 0.03 \\
\hline
\end{tabular}

[10] Statistically $X^{2} \mathrm{Cal}=31.63, \mathrm{df}=5, \mathrm{p}<0.05$ )

Ascaridoid larva 
Table 4-Distribution of the different parasites within female Bufo regularis

\begin{tabular}{|c|c|c|c|c|c|c|c|}
\hline Location & Parasite species & $\begin{array}{l}\text { No } \\
\text { found }\end{array}$ & $\begin{array}{l}\text { No } \\
\text { infected }\end{array}$ & Prevalence & $\begin{array}{l}\text { Total no of } \\
\text { parasites } \\
\text { collected }\end{array}$ & $\begin{array}{l}\text { Mean } \\
\text { intensity }\end{array}$ & $\begin{array}{l}\text { Mean } \\
\text { abundance }\end{array}$ \\
\hline Oesophagus & Ascaridoid larva & 2 & 1 & 3.03 & 2 & 2.00 & 0.06 \\
\hline Stomach & $\begin{array}{l}\text { a. A. larva } \\
\text { b. M. monodi } \\
\text { c.A.africanum }\end{array}$ & $\begin{array}{l}4 \\
7 \\
17\end{array}$ & 7 & $\begin{array}{l}12.12 \\
21.21 \\
51.51\end{array}$ & 28 & 4.00 & 0.85 \\
\hline Intestine & $\begin{array}{l}\text { a. A. larva } \\
\text { b. M monodi } \\
\text { c. Camallanus sp } \\
\text { d.A.africanum }\end{array}$ & $\begin{array}{l}29 \\
2 \\
6 \\
13\end{array}$ & 8 & $\begin{array}{l}87.88 \\
6.06 \\
18.18 \\
39.39\end{array}$ & 50 & 6.25 & 1.52 \\
\hline Rectum & $\begin{array}{l}\text { a. M. monodi } \\
\text { b.A.africanum }\end{array}$ & $\begin{array}{l}3 \\
7\end{array}$ & 2 & $\begin{array}{l}9.09 \\
21.21\end{array}$ & 10 & 5.00 & 0.30 \\
\hline Lungs & $\begin{array}{l}\text { a. M. monodi } \\
\text { b. R bufonis } \\
\text { c. Raillietiella sp }\end{array}$ & $\begin{array}{l}3 \\
63 \\
6\end{array}$ & 11 & $\begin{array}{l}9.09 \\
190.9 \\
18.18\end{array}$ & 72 & 6.55 & 2.18 \\
\hline Visceral cavity & $\begin{array}{l}\text { a. R. bufonis } \\
\text { b. A. larva }\end{array}$ & $\begin{array}{l}5 \\
1\end{array}$ & 2 & $\begin{array}{l}15.15 \\
3.03\end{array}$ & 6 & 3.00 & 0.18 \\
\hline
\end{tabular}

[10] Statistically $\left.\mathrm{X}^{2} \mathrm{Cal}=15.93, \mathrm{df}=5, \mathrm{p}<0.05\right)$

Table 3 and 4 show the distribution of the parasites species within the male and female toads. Parasites in the oesophagus of the male had a higher prevalence of $11.94 \%$ to females $3.03 \%$.parasites found in the stomach of males had a higher prevalence of $25.37 \%$ than females $21.21 \%$. Amplicaecum africanum, Mesocoelium monodi was found in the stomach of both male and female toads. Ascaridoid larva, Mesocoelium monody, camallanus sp and Amplicaecum africanum were found in the intestine of both male and female toads. Amplicaecum africanum was found in the rectum of both male and female toads. Rhabdias bufonis and Mesocoelium monodi were found in the lungs of both sexes. The differences were statistically significant. 